\title{
A possible relation between dietary zinc and cAMP in the regulation of tumour cell proliferation in the rat
}

\author{
BY NOEL S. SKEEF AND JOHN R. DUNCAN \\ Department of Chemistry and Biochemistry, Rhodes University, \\ Grahamstown 6140, South Africa
}

(Received 7 April 1987 - Accepted 7 December 1987)

1. The possibility of an effect of zinc on the rate of tumour cell division, mediated through a regulation of cellular cAMP concentration, was investigated in the present study in rats.

2. Dietary $\mathrm{Zn}$ deficiency $(<1.5 \mathrm{mg} \mathrm{Zn} / \mathrm{kg}$ ) but not $\mathrm{Zn}$ excess $(500 \mathrm{mg} \mathrm{Zn} / \mathrm{kg}$ ) resulted in an increased cAMP concentration in transplanted hepatoma cells. Neither treatment had any effect on the cAMP concentration in regenerating liver or normal resting liver. Both the deficient and excess $\mathrm{Zn}$ diets resulted in a small reduction in tumour growth (not statistically significant).

3. The results seem to indicate that the relation investigated in the present study does not apply in the cell line used.

A dietary zinc deficiency results in, among other disorders, general growth retardation (Prasad, 1979; Huang et al. 1982) as well as reduced carcinogenesis and tumour growth rate in certain types of cancers (Duncan et al. 1974; Duncan \& Dreosti, 1975; Minkel et al. 1979). In some cases these effects have also been shown to occur with a dietary $\mathrm{Zn}$ excess (Duncan \& Dreosti, 1975; Minkel et al. 1979). Experiments to date have associated this regulatory role of $\mathrm{Zn}$ on tumour growth exclusively with DNA synthesis (Slater et al. 1971; Duncan \& Dreosti, 1976; Minkel et al. 1979; Baker \& Duncan, 1983). More recently however, studies indicating an importance of $\mathrm{Zn}$ for $\omega 6$-fatty acid metabolism (Cunnane, 1982; Huang et al. 1982) have led to proposals of an alternative (or additional) mechanism of regulation involving cellular cAMP (Horrobin, 1980). In this mechanism, as illustrated in Fig. $1, \mathrm{Zn}$ is suggested to regulate the activity of $\Delta 6$-desaturase (a component of the

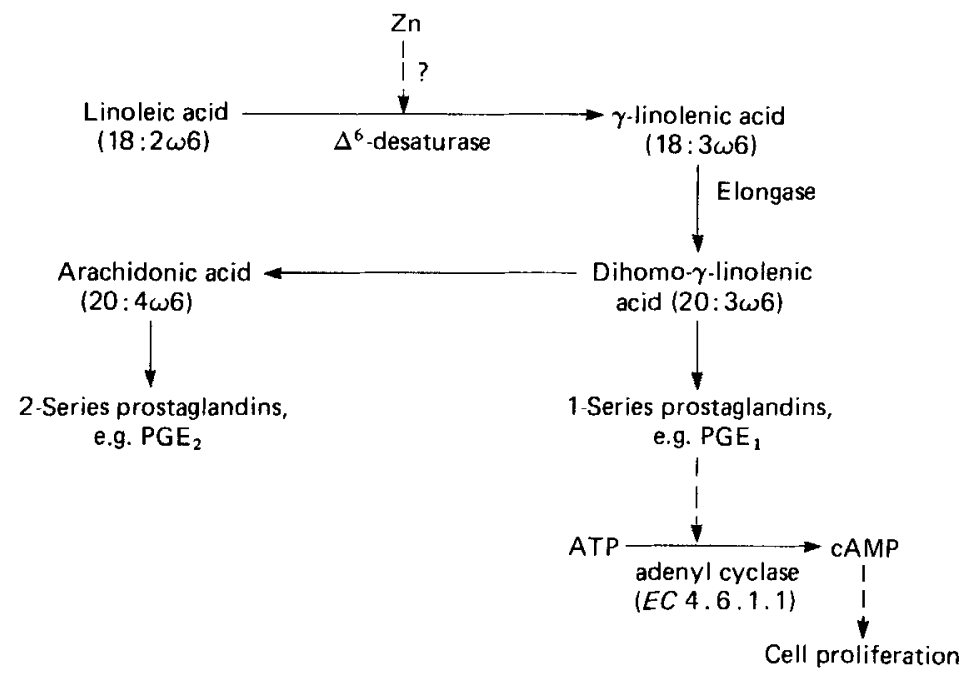

Fig. 1. An outline of the conversion of $\omega 6$-fatty acids to prostaglandins indicating the proposed site of action of zinc and the possible subsequent effect on the synthesis of cAMP and hence on cell proliferation (after Otten et al. 1971 and Huang et al. 1982). $\rightarrow$, Metabolic pathways; $--\rightarrow$, suggested effects. 
linoleoyl-CoA-desaturase complex), a key enzyme involved in the metabolism of linoleic acid to prostaglandins (Horrobin, 1980; Horrobin \& Cunnane, 1980; Huang et al. 1982). Prostaglandin $\mathrm{E}_{1}\left(\mathrm{PGE}_{1}\right)$ in particular has a strong stimulatory effect on cAMP accumulation in cells (Zor et al. 1970; Oien et al. 1975; Hall \& Behrman, 1982). cAMP in turn appears to have a regulatory role in cell proliferation and, in particular, in the transformation of certain cells (Otten et al. 1971; Sheppard, 1971, 1972). Studies concerning the previously mentioned relation are particularly significant considering that transformation of cells into cancer cells is often accompanied by a loss of $\Delta 6$-desaturase activity and a reduction in cAMP concentration (Otten et al. 1971; Sheppard, 1972; Dunbar \& Bailey, 1973). Hence it would seem that attempts to normalize cancer cells should consider enhancement of this enzyme activity or increasing cellular cAMP concentration, or both, where these are affected.

The purpose of the present study was to investigate an aspect of this relation, namely the effect of dietary $\mathrm{Zn}$ on cAMP concentrations and the growth of hepatomas implanted as tumours subcutaneously in rats, and to compare this with the effect of dietary $\mathrm{Zn}$ on the cAMP concentrations of non-transformed tissue, namely resting and regenerating livers.

MATERIALS AND METHODS

\section{Reagents}

A radioactive dilution cAMP test kit was purchased from Boehringer Mannheim, Randburg. Water-saturated diethyl ether was prepared by vigorously mixing 1 vol. distilled and deionized water with 5 vol. diethyl ether for 2 min and then separating the watersaturated diethyl ether from the aqueous phase.

\section{Animals and diets}

Female Wistar rats weighing $140-150 \mathrm{~g}$ were obtained from the Natal Institute of Immunology, Pinetown. They were housed in stainless-steel and plastic cages and given distilled and deionized drinking water $a d$ lib. to ensure that the diets were their only source of $\mathrm{Zn}$. The essentially $\mathrm{Zn}$-free ( $<1.5 \mathrm{mg} \mathrm{Zn/} \mathrm{kg}$ diet), biotin-enriched ( $4 \mathrm{mg} / \mathrm{kg}$ diet) basal diet consisted of $(\mathrm{g} / \mathrm{kg}) 670$ starch, 200 dried egg albumin, 80 maize oil, 40 salt mix, 10 vitamin mix (Mutch \& Hurley, 1974) and represented the Zn-deficient diet. A control diet was prepared by adding $\mathrm{ZnSO}_{4} .7 \mathrm{H}_{2} \mathrm{O}$ to the basal diet to provide a level of $\mathrm{Zn}$ equivalent to $50 \mathrm{mg} \mathrm{Zn} / \mathrm{kg}$ diet. The salt was added to a level of $500 \mathrm{mg} \mathrm{Zn} / \mathrm{kg}$ diet in the $\mathrm{Zn}$-excess diet.

In order to verify whether the results observed in the present study were a direct result of the $\mathrm{Zn}$ content of the diet or due to total food consumption, the effect of the diets on the growth of the rats was monitored in a separate study over $24 \mathrm{~d}$.

\section{Hepatoma cells}

Type 350 hepatoma is a $3^{\prime}$-methyl-4-dimethylaminoazobenzene-induced transplantable hepatoma and was supplied by Nola Dippenaar of the Department of Physiology, Medunsa.

\section{Surgical procedures}

Hepatoma cells to be transplanted into rats were harvested from in vitro cultures and suspended in phosphate-buffered saline $\left(5 \times 10^{6}\right.$ cells $\left./ \mathrm{ml}\right)$. Rats that had been feeding ad lib. on the experimental diet for 1 week were given subcutaneous injections of the cell suspension $(0.1 \mathrm{ml}$ in the abdominal area), After 4 weeks of continued feeding ad lib. on these diets, suitable-size tumours for the investigation under question had developed. These were dissected out, weighed and stored frozen $\left(-20^{\circ}\right)$. 
In a separate experiment rats were fed $a d$ lib. on the experimental diets for a period of 4 weeks after which they were anaesthetized with diethyl ether and partial hepatectomies (70\%) performed (Higgins \& Anderson, 1931). The fraction of liver removed served as the normal resting (non-regenerating) liver and the remaining fraction was allowed to regenerate over $24 \mathrm{~h}$ after which time the animals were killed and the remaining liver (regenerating) removed. Liver samples were stored at $-20^{\circ}$ for further analysis.

\section{Sample preparation for $c A M P$ determination}

Approximately $0.5 \mathrm{~g}$ of each of the tissues (resting liver, regenerating liver and tumour) was accurately weighed and homogenized using a dounce homogenizer (ten passes with the loose and twenty passes with the tight plunger) in $5 \mathrm{ml}$ cold $0.25 \mathrm{M}$-sucrose solution containing $3 \mathrm{mM}$-theophylline, an inhibitor of cAMP phosphodiesterase (EC 3.1.4.17) (Burk, 1968).

The procedure for the preparation of samples for cAMP determination was a modification of the methods of Gilman (1970), Walton \& Garren (1970) and Wastila et al. (1971). The previously described tissue homogenate was transferred into a dounce homogenizer and 3 vol. cold trichloroacetic acid (TCA) solution (with $3 \mathrm{~mm}$-theophylline), prepared so as to give a final concentration of $60 \mathrm{~g} \mathrm{TCA} / 1$ on addition, was added to precipitate proteins. This solution was further homogenized and allowed to stand at $0^{\circ}$ for $10 \mathrm{~min}$. It was then centrifuged at $46000 \mathrm{~g}$ at $0^{\circ}$ for $10 \mathrm{~min}$ (J2-21 centrifuge and JA-21 rotor; Beckman). The supernatant fraction was removed and washed three times with 10 vol. water-saturated diethyl ether. Residual diethyl ether was removed in a stream of hot $\left(70^{\circ}\right)$ air, the disappearance of the diethyl ether odour marking the end-point.

The method used for the determination of cAMP concentration was a protein-binding assay based on the method of Gilman (1970) and described fully in the cAMP test kit.

\section{Statistical analysis}

The statistical significance of differences between means and their standard errors was tested by Student's $t$ test.

\section{RESULTS \\ Growth of animals}

In a separate study it was found that the growth of rats fed on the $\mathrm{Zn}$-deficient and $\mathrm{Zn}$ excess diets was lower than that of the control group even when the controls were pair-fed with the $\mathrm{Zn}$-deficient and $\mathrm{Zn}$-excess groups (Fig. 2). In the main experiment, however, all dietary groups were fed $a d$ lib. and growth of animals in this study was similar to that reported above.

\section{Weight and cAMP concentration of tumours}

The mean weights of tumours removed from rats fed on the $\mathrm{Zn}$-deficient and those fed on the $\mathrm{Zn}$-excess diets were both lower than of those from the control group, but this reduction was not statistically significant (Table 1). This was accompanied by an increase in the cAMP concentration of the tumours from both the $\mathrm{Zn}$-deficient and $\mathrm{Zn}$-excess animals of 40 and $30 \%$ respectively compared with the control group, that of the $\mathrm{Zn}$-deficient group being statistically significant $(P<0.05)$.

\section{cAMP concentration of normal resting and regenerating livers}

There was essentially no change in the cAMP concentration of normal resting livers from both the $\mathrm{Zn}$-deficient and $\mathrm{Zn}$-excess animals when compared with the corresponding control (6 and $0.9 \%$ respectively; Table 2 ). The increase in cAMP concentration of 

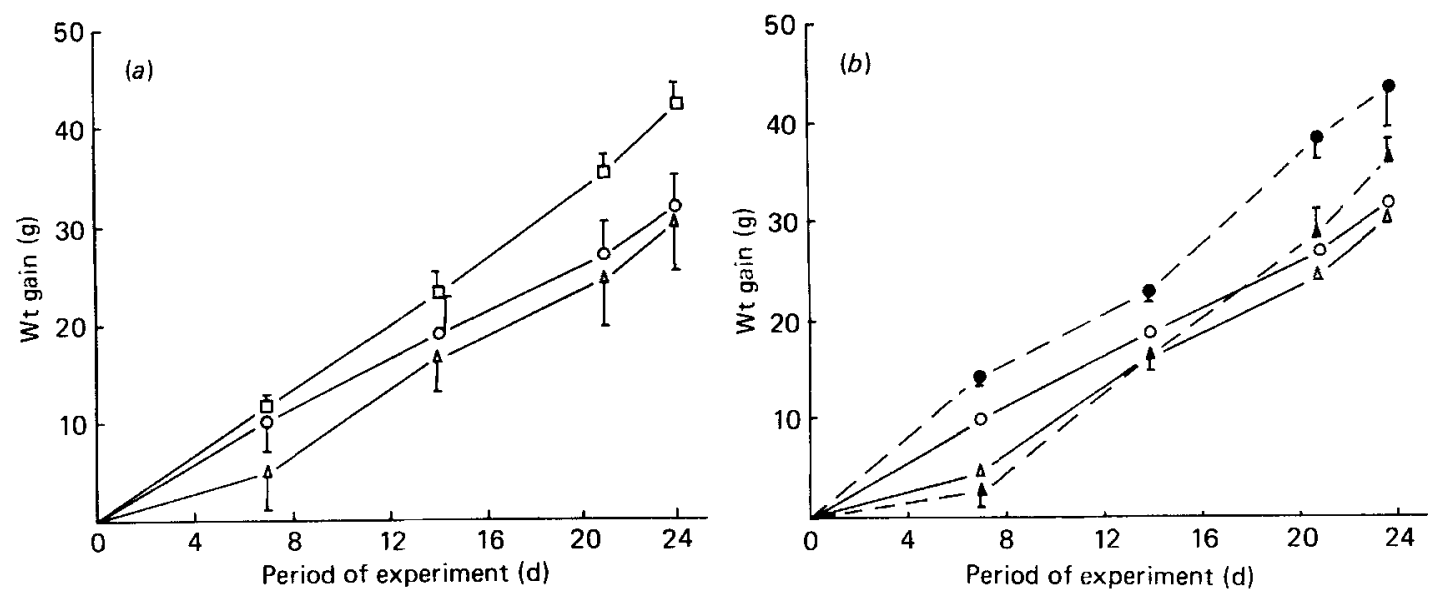

Fig. 2. Effect of dietary zinc on the weight gain of rats. (a) Groups $1(O), 2(\triangle)$ and $3(\square)$ fed ad lib. on $\mathrm{Zn}$-deficient, $\mathrm{Zn}$-excess and control diets respectively. (b) Groups 4 (O) and 5 (A) were given the control diet in an amount equivalent to that consumed by groups $1(O)$ and $2(\triangle)$ respectively. Points represent means from four animals with their standard errors representated by vertical bars. For details of diets, see p. 438.

Table 1. Effect of dietary zinc on the growth and cAMP concentration of type 350 hepatomas grown subcutaneously in rats for a period of 4 weeks

(Mean values with their standard errors for eight samples)

\begin{tabular}{|c|c|c|c|c|}
\hline \multirow[b]{2}{*}{ Diet $\dagger$} & \multicolumn{2}{|c|}{$\begin{array}{l}\text { Weight of tumour } \\
(\mathrm{g})\end{array}$} & \multicolumn{2}{|c|}{$\begin{array}{c}\text { cAMP } \\
\text { concentration } \\
(\mathrm{pmol} / \mathrm{mg} \text { tissue) }\end{array}$} \\
\hline & Mean & $\mathrm{SE}$ & Mean & SE \\
\hline Zn-deficient & $2 \cdot 87$ & 0.55 & $1 \cdot 158^{*}$ & $0 \cdot 131$ \\
\hline Control (ad lib.) & 4.97 & 0.96 & 0.825 & 0.074 \\
\hline Zn-excess & $3 \cdot 23$ & $1 \cdot 04$ & $1 \cdot 074$ & 0.095 \\
\hline
\end{tabular}

Significantly different from control value: $* P<0 \cdot 05 . \dagger$ For details, see p. 438

Table 2. Effect of dietary zinc on cAMP concentration in resting and regenerating rat livers from rats fed on a $\mathrm{Zn}$-deficient, control or Zn-excess diet for 4 weeks

(Mean values with their standard errors for eight samples)

\begin{tabular}{|c|c|c|c|c|}
\hline \multirow[b]{3}{*}{ Diet* } & \multicolumn{4}{|c|}{ cAMP concentration (pmol/mg tissue) } \\
\hline & \multicolumn{2}{|c|}{ Resting liver } & \multicolumn{2}{|c|}{ Regenerating liver } \\
\hline & Mean & $\mathrm{SE}$ & Mean & $\mathrm{SE}$ \\
\hline Zn-deficient & 0.564 & 0.052 & $0 \cdot 760$ & 0.061 \\
\hline Control (ad lib.) & 0.532 & 0.037 & $0 \cdot 641$ & 0.025 \\
\hline Zn-excess & 0.527 & 0.023 & 0.706 & 0.056 \\
\hline
\end{tabular}

* For details, see p. 438. 
regenerating livers from $\mathrm{Zn}$-deficient and $\mathrm{Zn}$-excess animals (19 and $10 \%$ respectively when compared with the corresponding control), though not significant, was greater than that of the normal resting livers but less than that of the tumours.

An interesting comparison was the relative concentrations of cAMP in the three tissue types examined. Both regenerating liver and tumour tissue had higher levels than normal resting liver, with that of the tumours being the highest (Tables 1 and 2).

\section{DISCUSSION}

The observed effect of the $\mathrm{Zn}$-deficient diet in reducing the growth of rats is in agreement with results reported by other workers (Prasad, 1979; Huang et al. 1982). The similar effect of the $\mathrm{Zn}$-excess diet is particularly interesting and supports earlier observations of a similar effect of these extreme dietary conditions (Duncan \& Dreosti, 1975; Minkel et al. 1979). The fact that pair-fed controls had a moderately higher weight gain than the corresponding $\mathrm{Zn}$-deficient and $\mathrm{Zn}$-excess groups indirectly indicated that it was unlikely that the effects of the experimental $\mathrm{Zn}$ diets on the other variables examined were due to a difference in energy intake but were a direct result of the different $\mathrm{Zn}$ levels in the diets.

Increased cellular cAMP concentrations have generally been associated with reduced cell proliferation (Otten et al. 1971; Sheppard, 1971, 1972). Since both a dietary Zn-deficiency and $\mathrm{Zn}$-excess have been found to result in reduced tumour growth (Duncan et al. 1974; Duncan \& Dreosti, 1975) and, furthermore, since there have been indirect indications of a requirement for $\mathrm{Zn}$ by $\Delta 6$-desaturase (Cunnane, 1982; Huang et al. 1982), a relation between $\mathrm{Zn}, \mathrm{cAMP}$ and cell proliferation, as indicated in Fig. 1, is implicated. In the present study although the reduction in hepatoma growth due to $\mathrm{Zn}$ deficiency was not significant, the latter was associated with a significant elevation in cAMP concentration. While $\mathrm{Zn}$ excess did reduce tumour growth and elevate cAMP levels to a certain extent this effect was not significant in either case. These findings suggest that it is only $\mathrm{Zn}$ deficiency and not $\mathrm{Zn}$ excess that has a stimulatory effect on cAMP synthesis, and that this effect is selective for the hepatoma cells. While the apparent inverse relation between cAMP and cell division would seem to be in support of the hypothesis being investigated, the fact that stimulation of cAMP accumulation resulted from a $\mathrm{Zn}$ deficiency rather than from a $\mathrm{Zn}$ excess would seem to contradict this hypothesis. It would therefore seem from these results that the regulation of cell division through the mechanism proposed earlier (p. 437) is not necessarily valid in the cells used in the present study. However, the possibility still exists that in other cell types $\mathrm{Zn}$ may regulate tumour cell growth through this mechanism. What the exact site of action of $\mathrm{Zn}$ may be remains to be identified by more detailed investigations of the pathways concerned.

Further studies should perhaps be done using in vitro cultured tumour cells to define more clearly the exact role of $\mathrm{Zn}$ in these cells and should attempt to investigate more directly the possible relation between $\mathrm{Zn}$ and $\Delta 6$-desaturase activity. Preliminary studies with this in mind have been carried out in this laboratory using another cancer-cell line and have indicated that $\mathrm{Zn}$ addition to the culture medium stimulates $\Delta 6$-desaturase activity (N. S. Skeef and J. R. Duncan, unpublished results).

The authors are grateful to the Council for Scientific and Industrial Research (CSIR), RSA for funds granted towards this research. 


\section{REFERENCES}

Baker, G. W. \& Duncan, J. R. (1983). Journal of the National Cancer Institute 70, 333-336.

Burk, R. R. (1968). Nature 219, 1272-1275.

Cunnane, S. C. (1982). British Journal of Nutrition 47, 495-504.

Dunbar, L. M. \& Bailey, J. M. (1973). Journal of Biological Chemistry 250, 1152-1153.

Duncan, J. R. \& Dreosti, I. E. (1975). Journal of the National Cancer Institute 55, 195-196.

Duncan, J. R. \& Dreosti, I. E. (1976). South African Medical Journal 50, 711-712.

Duncan, J. R., Dreosti, I. E. \& Albrecht, C. F. (1974) . Journal of the National Cancer Institute 53, 277-278.

Gilman, A. G. (1970). Proceedings of the National Academy of Sciences, USA 67, 305-312.

Hall, A. K. \& Behrman, H. R. (1982). In Prostaglandins, pp. 1-37 [J. B. Lee, editor]. New York: Elsevier.

Higgins, G. \& Anderson, P. M. (1931). Archives of Pathology 12, 186-202.

Horrobin, D. F. (1980). Medical Hypotheses 6, 277-296.

Horrobin, D. F. \& Cunnane, S. C. (1980). Medical Hypotheses 6, 277-296.

Huang, Y. S., Cunnane, S. C., Horrobin, D. F. \& Davignon, J. (1982). Artherosclerosis 41, 193-207.

Minkel, D. T., Dolhun, P. J., Calhoun, B. L., Saryan, L. A. \& Petering, D. H. (1979). Cancer Research 39, 2451-2456.

Mutch, P. B. \& Hurley, L. S. (1974). Journal of Nutrition 104, 828-842.

Oien, H. G., Mandel, L. R., Humes, J. L., Taub, D., Hofsummer, R. D. \& Kuehl, F. A. Jr (1975). Prostaglandins 9, 985-995.

Otten, J., Johnson, G.S. \& Pastan, I. (1971). Biochemical and Biophysical Research Communications 44, $1192-1198$.

Prasad, A. S. (1979). Annual Review of Pharmacology and Toxicology 20, 393-426.

Sheppard, J. R. (1971). Proceedings of the National Academy of Sciences, USA 68, 1316-1320.

Sheppard, J. R. (1972). Nature 236, 14-16.

Slater, J. R., Mildvan, A. S. \& Loeb, L. A. (1971). Biochemical and Biophysical Research Communications 44, $37-43$.

Walton, G. M. \& Garren, D. L. (1970). Biochemistry 9, 4223-4229.

Wastila, W. B., Stull, J. T., Mayer, S. E. \& Walsh, D. A. (1971). Journal of Biological Chemistry 246, 1996-2003.

Zor, U., Kaneko, T., Schneider, H. P. G., McCann, S. M. \& Field, J. B. (1970). Journal of Biological Chemistry 245, 2883-2888. 